\title{
Impact of Unhairing Liquor and Chromium Spent Solution Recycling as an Alternative Treatment Option in Leather Industry
}

\author{
Alim Abd Elgadir Haj Ali* \\ Department of National Leather Technology Center, Sudan \\ *Corresponding author: Alim Abd Elgadir Haj Ali, Department of National Leather Technology Center, Industrial Researcher and \\ Consultant Center, Khartoum, Sudan.
}

To Cite This Article: Alim Abd Elgadir Haj Ali. Impact of Unhairing Liquor and Chromium Spent Solution Recycling as an Alternative Treatment Option in Leather Industry. Am J Biomed Sci \& Res. 2019 - 2(2). AJBSR.MS.ID.000572. DOI: 10.34297/AJBSR.2019.02.000572

Received: March 18, 2019 | Published: March 28, 2019

\begin{abstract}
Hides and skins need treatment to be leather, this treatment processing pass from soaking to retainage which require chemicals including preservatives, salt, lime, sodium sulphide, ammonium sulphate, bating materials, acids and alkalis. These chemicals and proteins are much polluted and need to be treated to protect the environment however the treatment is not efficient and considerable amount of chemicals and water are drained. On the other hand the recycling method save chemicals, water, protects the environment and that no waste treatment plant is needed, the study was done in National Leather Technology Center, Sudan where ten trials were carried out for recycling, for each process from soaking, liming to tanning as show in tables, This reduces the cost of the product and gives more protection to the environment. So, it is recommended that the method of recycling is to be generalized to all tanneries.
\end{abstract}

Keywords: Hides and Skins, Lime, Chrome, Tannage, Pollution, Recycling, Environment, Carcinogenic, Leather

\section{Introduction}

Leather tannage has emerged as an important economic activity in several developing countries and as a result of increased awareness of environmental problems, environmental protection has become a global issue in recent years. Currently the leather processing industry is going through a phase change due to global environmental regulations. The pretannage and tannage revealed that pretanning and tanning processes contribute $80-90 \%$ of the total pollution load $\left(\mathrm{BOD}_{5}, \mathrm{COD}, \mathrm{TS}, \mathrm{TDS}, \mathrm{Cr}^{+3}, \mathrm{~S}^{2-}\right.$, sludge, etc.). Further, toxic gases like ammonia and hydrogen sulfide are also emitted. Volatile organic compounds, heavy metals, and carcinogenic aryl-amines from post-tanning and finishing operations are also creating severe concern. [1] Where the pollution load of untreated lime-sulphide effluent $\left(\mathrm{S}^{2-}, \mathrm{Ca}(\mathrm{OH})_{2}\right.$, COD, TS) content is 588, 2960, 31010 and 32160 ppm respectively [2]. In this context the wastewater resulting from tanning processes contains high amount of chromium metal which is harmful for the environment and human health. Tanning is the chemical process that converts animal hides and skins into stable and imputrescible products called leather [3]. While that Buljan \& Kral [4] reported that it is a vital industrial process to produce leather from raw hides and skins. Yet, the process gives a problem to the environment. The transformation of hides into leather is usually done by means of tanning agents and the process generates highly turbid, colored and foul-smelling effluent [4]. More than $600 \mathrm{~kg}$ of solid waste is generated during the transformation of leather where present in the constituent of solid wastes are fleshing, fats, solid hair debris, trimmings, shavings and leather cuttings [5]. An additional source of solid waste is the sludge from the effluent treatment plant whereas the solid waste generated from processing one tone (equaling 1,000 kilograms) of raw hides using the conventional processing techniques is approximately $70 \mathrm{~kg}$, with the largest quantity being generated from beam house operations, [6] of world tanneries, 80$90 \%$ use chromium (III) salts in their tanning processes. The degree of toxicity of chrome is perhaps one of the most debated issues between the tanning industry and authorities [7]. Chromium salts which are not fixed to the collagen during the tanning process are discharged as effluents to the environment, notably water and the ground. Water - It has been estimated that, with traditional tanning methods, from 4 to $9.5 \mathrm{~kg}$ of chromium (calculated as $\mathrm{Cr}_{2} \mathrm{O}_{3}$ ) per ton of skins are not chemically fixed during processing if it is not carried out with a suitable high exhaustion tanning system [8]. Therefore, chromium from leather tanning can make its way into air, soil, food, and water, and the most common forms of exposure are through inhalation of dust or fumes and ingestion of or contact with contaminated water. Workers in tanning facilities can inhale airborne chromium and can also be exposed through dermal 
contact Wastewater and solid waste from tanning operations often find their way into surface water, where toxins are carried downstream and contaminate water used for bathing, contaminate cooking, swimming, and irrigation. Chromium waste also seeps into the soil and groundwater systems that provide drinking water for nearby communities. Therefore, the objective of this study is to recycle wet processes from soaking through retaining and to check the quality of the leather made through recycling to that produced by the conventional methods.

\section{Materials and Methods}

The goat pelts were obtained from warehouse in Omdurman, Khartoum. Sudan. Reagents used for the experiment and analysis were of analytical grade.

\section{Experimental design}

The experimental design was outlined in randomized complete

\begin{tabular}{|c|c|c|c|c|c|c|c|}
\hline \multirow{2}{*}{ Process } & \multirow{2}{*}{$\%$} & \multirow{2}{*}{ Product } & \multirow{2}{*}{ Time } & \multirow{2}{*}{ Remarks } & \multicolumn{2}{|c|}{$\mathrm{pH}$} & \multirow{2}{*}{ Real Time } \\
\hline & & & & & Skin & Float & \\
\hline Washing & 200 & Water at $28^{\circ} \mathrm{C}$ & $30^{\prime}$ & & & & \\
\hline \multicolumn{8}{|l|}{ Drain } \\
\hline \multirow[t]{3}{*}{ unhairing } & 150 & Water at $28^{\circ} \mathrm{C}$ & & & & & \\
\hline & 6 & Lime & 60 & & & & \\
\hline & 3 & Sodium sulphide & $60^{\prime}$ & $\begin{array}{l}\text { Overnight and run } \\
10^{\prime} / \mathrm{h}\end{array}$ & & $\mathrm{pH}=12.5$ & \\
\hline Next Morning & Run & $10^{\prime}$ & $\begin{array}{l}\text { Liquor was filtered by screen and } \\
\text { saved to recycle trials }\end{array}$ & $\begin{array}{l}\text { Drain/Wash/ } \\
\text { Drain/ Reliming }\end{array}$ & & & \\
\hline
\end{tabular}

design with two treatments; $\mathrm{T}_{1}$ : traditional method; without recycle; and $\mathrm{T}_{2}$ : recycle methods; methods replicated three times.

\section{Tanning trials}

Green goat skins have been used for pre-tanning are shown in (Table 1) as a control leather, and amount of water, sodium sulphide and calcium hydroxide used for the pre-tanning trials has been $150 \%, 3 \%$ and $6 \%$ respectively, the obtained pelts were prepared to re-lime stage. The drum content was discharged in the saving container and filtered then pumped again into drum and the process was continued subsequently then water sodium sulphide and lime in filtered liquor were measured and then bath corrected to $150 \%, 3 \%$ and $6 \%$ based on weight of soaking pelts respectively. The experiment was repeated 9 times using remained filtered unhairing liquor from the previous trial each time according to percentage declared in Table 2 . The experiments of pre-tannage were continued according to the method mentioned in Table 3 using produced unhairing pelts to produce chrome tanned leathers.

\begin{tabular}{|c|c|c|c|c|c|c|c|}
\hline \multirow{2}{*}{\multicolumn{2}{|c|}{ No }} & \multicolumn{2}{|c|}{ Water $150 \%$} & \multicolumn{2}{|c|}{ Sodium sulphide $3 \%$} & \multicolumn{2}{|c|}{ Calcium hydroxide $6 \%$} \\
\hline & & \multirow{2}{*}{$\begin{array}{c}\text { Saved } * \% \\
-\end{array}$} & \multirow{2}{*}{$\begin{array}{c}\text { Added } \% \\
150\end{array}$} & \multirow{2}{*}{$\begin{array}{c}\text { Saved }{ }^{* \%} \\
-\end{array}$} & \multirow{2}{*}{$\begin{array}{c}\text { Added } \% \\
3\end{array}$} & \multirow{2}{*}{$\begin{array}{c}\text { Saved }{ }^{* \%} \\
-\end{array}$} & \multirow{2}{*}{$\begin{array}{c}\text { Added } \% \\
6\end{array}$} \\
\hline $\mathrm{T} 1$ & $1^{*}$ & & & & & & \\
\hline \multirow{9}{*}{$\mathrm{T} 2$} & 2 & 120 & 30 & 1.4 & 1.6 & 1.4 & 4.4 \\
\hline & 3 & 127.5 & 22.5 & 1.3 & 1.7 & 1.3 & 4.7 \\
\hline & 4 & 120 & 30 & 1.2 & 1.8 & 1.2 & 4.8 \\
\hline & 5 & 120 & 30 & 1.2 & 1.8 & 1.2 & 4.8 \\
\hline & 6 & 112.5 & 37.2 & 1.1 & 1.9 & 1.1 & 4.9 \\
\hline & 7 & 115.5 & 34.5 & 1.4 & 1.6 & 1.4 & 4.6 \\
\hline & 8 & 126 & 24 & 1.1 & 1.9 & 1.1 & 4.9 \\
\hline & 9 & 126 & 24 & 1.1 & 1.9 & 1.1 & 4.9 \\
\hline & 10 & 115.5 & 34.5 & 1.45 & 1.55 & 1.45 & 4.55 \\
\hline Total & 120 & 30 & 1.25 & 1.75 & 1.25 & 4.75 & \\
\hline
\end{tabular}

Table 3: Re-lime, batting, Pickling and chrome tannage trials.

\begin{tabular}{|c|c|c|c|c|c|c|c|}
\hline \multirow{2}{*}{ Process } & \multirow{2}{*}{$\%$} & \multirow{2}{*}{ Product } & \multirow{2}{*}{ Time } & \multirow{2}{*}{ Remarks } & \multicolumn{2}{|c|}{ pH } & \multirow{2}{*}{$\begin{array}{c}\text { Real } \\
\text { Time }\end{array}$} \\
\hline & & & & & Skin & Float & \\
\hline Drain/Wash/Drain & 200 & Water at $28^{\circ} \mathrm{C}$ & $10^{\prime}$ & & & & \\
\hline \multirow[t]{2}{*}{ Reliming } & 100 & Water at $28^{\circ} \mathrm{C}$ & & & & & \\
\hline & 2 & Lime & $30^{\prime}$ & & & $\mathrm{pH}=12.5$ & \\
\hline Drain/Wash/Drain & 200 & Water at $28^{\circ} \mathrm{C}$ & $30^{\prime}$ & & & & \\
\hline
\end{tabular}




\begin{tabular}{|c|c|c|c|c|c|c|}
\hline Drain/Wash/Drain & 200 & Water at $28^{\circ} \mathrm{C}$ & $10^{\prime}$ & & & \\
\hline \multirow[t]{2}{*}{ Neutralization } & 100 & Water at $28^{\circ} \mathrm{C}$ & & & & \\
\hline & 1.5 & Sodium formate & 60 & & & $\mathrm{pH}=8$ \\
\hline Drain/Wash/Drain & 100 & Water at $28^{\circ} \mathrm{C}$ & $20^{\prime}$ & & & \\
\hline \multirow[t]{2}{*}{ Batting } & 80 & Water at $30^{\circ} \mathrm{C}$ & & & & \\
\hline & 1 & Orbon & $30^{\prime}$ & Check FFT & OK & $\mathrm{pH}=7,0 / 7,2$ \\
\hline Drain/Wash/Drain & 200 & Water at $28^{\circ} \mathrm{C}$ & $10^{\prime}$ & & & \\
\hline Drain/Wash/Drain & 200 & Water at $28^{\circ} \mathrm{C}$ & $10^{\prime}$ & & & \\
\hline \multirow[t]{4}{*}{ Pickling } & 60 & Water at $28^{\circ} \mathrm{C}$ & & & & \\
\hline & 10 & Salt & $10^{\prime}$ & bring to Bé $=6$ & & \\
\hline & 1 & Formic Acid (1: 5) & $30^{\prime}+30^{\prime}$ & & & \\
\hline & 0.4 & Sulphuric Acid (1: 10) & $30^{\prime}+30^{\prime}$ & STOP Overnight & & \\
\hline \multicolumn{7}{|c|}{ Next Morning } \\
\hline \multirow[t]{7}{*}{ RUN } & & & $10^{\prime}$ & & bcg=yellow & $\mathrm{pH}=3,0 / 3,1$ \\
\hline & 4 & Chrome 26/33 & $60^{\prime}$ & & & \\
\hline & 1 & Sod. Formate & $30^{\prime}$ & & & \\
\hline & 4 & Chrome 26/33 & $180^{\prime}$ & & & \\
\hline & 0.1 & Fungicide & & & & \\
\hline & 1 & Sod. Formate & $30^{\prime}$ & & & \\
\hline & 50 & Water at $28^{\circ} \mathrm{C}$ & & STOP Overnight & & \\
\hline \multicolumn{7}{|c|}{ Next Morning } \\
\hline & 0.6 & Sod. Bicarbonate & $30^{\prime}+30^{\prime}$ & (add in 2 times) & BCG=Blue & $\mathrm{pH}=3,8 / 4$ \\
\hline & 50 & Water at $45^{\circ} \mathrm{C}$ & $40^{\prime}$ & & & \\
\hline $\begin{array}{l}\text { Mechanical } \\
\text { Operations }\end{array}$ & & $\begin{array}{l}\text { Pile Up / Sammy / } \\
\text { Shave / Re-Tannage }\end{array}$ & & & & \\
\hline
\end{tabular}

The drum content was saved, and the process was continued wherefore remained chroming liquor were measured, and bath completed to $60 \%$ of water based on weight of de-liming pelts, then the $\mathrm{pH}$ of solution was adjusted to 2.8 utilized formic acid diluted (1:10) and sulphuric acid. Then amount of chrome content was corrected to required amount, and the experimental was continued according to Table 4 and the experimental was continued according to Table 3 and the produced crust leathers were prepared to the post tannage stage (Table 5).

\begin{tabular}{|c|c|c|c|c|c|c|}
\hline \multirow{2}{*}{\multicolumn{2}{|c|}{ Trail }} & \multicolumn{3}{|c|}{ Water $60 \%$} & \multicolumn{2}{|c|}{ Chrome sulphate $24 / 33$} \\
\hline & & \multirow{2}{*}{$\begin{array}{c}\text { Saved\% } \\
-\end{array}$} & \multirow[t]{2}{*}{$\mathrm{pH} /$ before } & \multirow{2}{*}{$\begin{array}{c}\text { Added } \% \\
60\end{array}$} & \multirow{2}{*}{$\begin{array}{c}\text { Saved\% } \\
-\end{array}$} & \multirow{2}{*}{$\begin{array}{c}\text { Added\% } \\
8\end{array}$} \\
\hline $\mathrm{T} 1$ & 1 & & & & & \\
\hline \multirow[t]{9}{*}{$\mathrm{T} 2$} & 2 & 55 & 3.8 & 5 & 2.4 & 5.6 \\
\hline & 3 & 54.5 & 3.8 & 5.5 & 2.6 & 5.4 \\
\hline & 4 & 53.5 & 4 & 6.5 & 2.7 & 5.3 \\
\hline & 5 & 53.5 & 3.8 & 6.5 & 1.9 & 6.1 \\
\hline & 6 & 55 & 3.9 & 5 & 3 & 5 \\
\hline & 7 & 50 & 3.8 & 10 & 2.4 & 5.6 \\
\hline & 8 & 47.5 & 4 & 12.5 & 3.1 & 4.9 \\
\hline & 9 & 49 & 3.8 & 11 & 2.1 & 5.9 \\
\hline & 10 & 48 & 3.9 & 12 & 2.4 & 5.6 \\
\hline Total & & 51.8 & & 8.2 & 2.5 & 5.5 \\
\hline
\end{tabular}

The experiment was repeated 9 time using remained chroming liquor from the previous trial each time according to percentage declared in Table 4.
The method was continued using the chrome tanned leather using post tannage method mentioned in table 5; and the produced leathers were stored to mechanical and physic-chemical tests. 


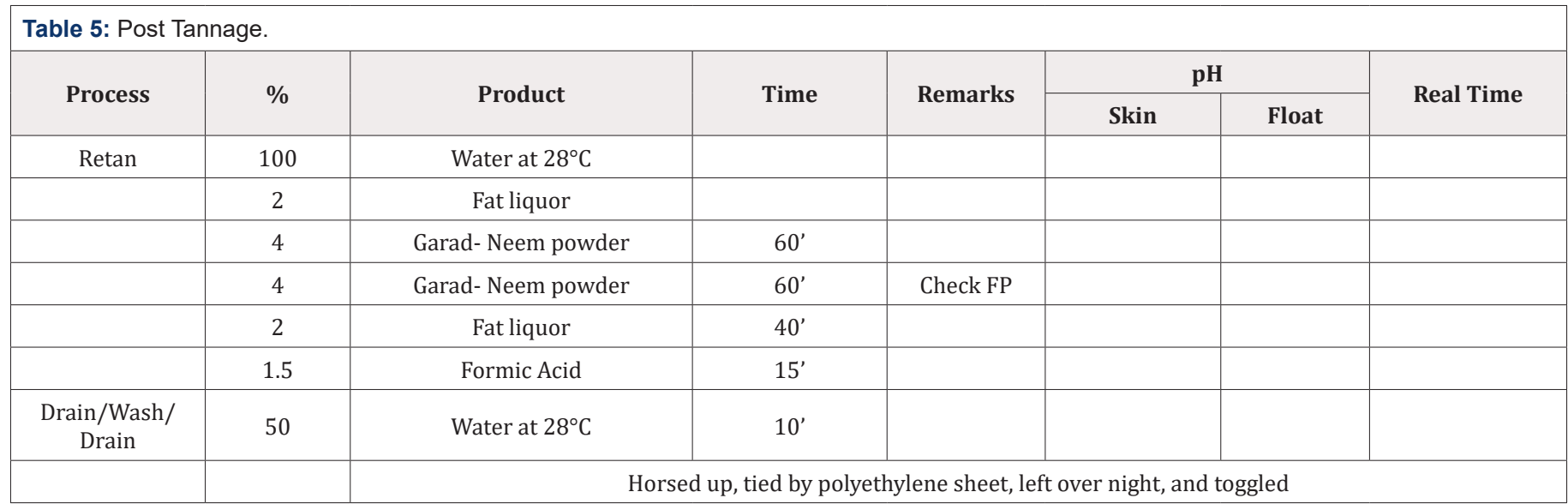

\section{Physio- chemical properties of wastewater}

Wastewater characterization was done for the physic-chemical quality parameters; $\mathrm{pH}$, TSS, TDS. $\mathrm{BOD}_{5}, \mathrm{COD}$, and total chromium content according to ASTM [9-12]

Table 6: Physico-chemical characteristics of wastewater.

\begin{tabular}{|c|c|c|c|c|c|c|c|c|c|c|}
\hline \multirow{2}{*}{ Parameter } & \multicolumn{5}{|c|}{ Un-haring } & \multicolumn{5}{|c|}{ Tanning } \\
\hline & T1 & T2 & mean & Std.D & Sig/0.5 & T1 & T2 & Mean & Std.D & $\mathrm{Sig} / 0.5$ \\
\hline $\mathrm{PH}$ & 12.5 & 12.6 & 12.64 & 0.144 & 0.94 & 3.85 & 3.9 & 3.89 & 0.081 & 0.968 \\
\hline BOG5 & 1710 & 1823.32 & 1766.66 & 162.09 & 0.29 & 277.5 & 454.28 & 365.89 & 89.34 & 0.351 \\
\hline COD & 18578 & 22892.3 & 20705.15 & 54.37 & 0 & 1716 & 2954.86 & 2335.43 & 891.99 & 0.351 \\
\hline TDS & 15157 & 18429.48 & 16793.24 & 7330.06 & 0 & 13148.5 & 16527.9 & 14838.2 & 3260.87 & 0.26 \\
\hline TSS & 6804 & 6922.36 & 6863.18 & 309.86 & 0 & 405 & 404.28 & 406.14 & 52.32 & 0.35 \\
\hline Sulphide & 2967 & 3273.5 & 3120 & 127.5 & 0.006 & 375 & 421.3 & 401.2 & 19.36 & 0.029 \\
\hline Chrome & - & - & - & - & - & 1.46 & 2.86 & 2.016 & 0.629 & 0.275 \\
\hline
\end{tabular}

\section{The mechanical properties of leather}

The samples were prepared according to SLP1\&2 then the specimens were subjected to conditioning according to SLP3. Shrinkage temperature (SLC406), thickness, tensile strength and elongation were measured according to (SLP 4, 6 and 7). [13]

\section{Statistics Analysis}

The data mechanical, physicochemical analyzed using the statistical package for science (SPSS) at a significant level $p=0.05$ using (ANOVA). [14]

\section{Results and Discussions}

Both of experimental trials were separately run for recycling lime-unhairing and chrome liquors for 10 times, in each case the residuals were filtered and then calculated water, lime, sodium sulphide and chrome, and each run was topped with the required make up according to Tables $2 \& 4$ which illustrate the percent of chemicals components contribution in the trials.

To avoid fat builds in lime liquors which practice proved to be a problem as it may cause greasy leather or adhere to the drum and be difficult to remove. Thus, used of green-fleshed skins and/or surfactants may overcome the problem and/or stopped recycling repeated after 10 times and/or removed it mechanically or established new recycling trial.
Tables 3 \& 5 explain that by increasing the recycling times number observed that the average of water consumption per kilogram was reduced. Since that consumption was reduced to $82 \%$ therefore the wastewater production also was reduced to about $18 \%$ and contribution of other chemicals components such as sulphide, lime and chrome, 52.5, 18.9 and $62 \%$ respectively in the total load of waste water.

This means that the recycle have an impact on the local level especially that methods of waste water treatment requires a treatment plant, chemicals, and laborers and mentalist. This increases the cost and so reduced the profit. This guided us think of used recycling, a process which saves chemicals, water, and protect the environment.

The results explain that the chemical oxygen demand is a measure of the chemical reducing power of effluent and hence its ability to destroy potential oxygen content of water. The results indicated that throughout recycling trials, COD levels were nonconforming to that calculated of traditional tanned waste water. This value is also high relative to the results measured. This pointed to repeated of processes that generate COD were early stages such as liming (which dissolves the skins' epidermis and material that cements skin fibers together) and the degreasing and dry-cleaning processes to remove fats and greasy materials. 
The solids waste generation is an inherent part of leather processing wherefore the low levels of skill in the flaying and fleshing of skins operation and repeated of utilized un-hair liquor for 10 times may cause an increasing of total suspended solid in the effluent compared to that measure of unhairing liquor which was discharged directly, though, the levels of pollution of the collected waste water had improved which was pegged to the numbers of trials and amount of total suspended solids which was assisted after 10 recycling.

Sulphides constitute one of the most dangerous pollutants whereas the major contributor to sulphide pollution is unhairing operation, which uses sodium sulphide. Processes that generate sulphate in their waste liquors also contribute to sulphide pollution also oxygen deficient waters, sulphate are reduced to sulphide, whereas the sulphate are generated by three stages namely de-lime, pickle and tannage therefore the de-lime stage uses ammonium sulphate, the pickle stage uses sulphuric acid and trials the tannage stage uses chrome sulphate. In both recipes' sodium format was utilized as alternative to ammonium sulphate in the de-liming stage to reduce the sulfates content in the effluent. The results indicated that throughout recycling, sulphide levels were decreased to almost ten times of that calculated of traditional tanned waste water.

The results were highly impressive, where it was known that when chrome bearing were recycle where the calculated parameters illustrated that the chrome content was reduced to minimum level compared to traditional method in which discharged the tannins liquor directly after chrome fixation, this may attribute technically to their high exhaustion and the rigorous process control which optimizes chromium uptake in the skin, and so environmentally, chrome is of more concern so applied saving and recycling of tanning liquors represented rigorous method of effluent treated. Therefore, applied separate treatment of chrome streams is necessary for limiting its content in waste water, even in those tanneries achieving high exhaustion.

Table 7: the mechanical properties for both controlled and recycled leathers.

\begin{tabular}{|c|c|c|c|c|c|c|c|c|c|c|c|c|c|c|}
\hline \multirow[t]{2}{*}{ Trails } & \multicolumn{5}{|c|}{ T1 } & \multicolumn{5}{|c|}{ T2 } & T3 & \multirow{2}{*}{ Mean } & \multirow{2}{*}{ Std.D } & \multirow{2}{*}{ Sig/0.5 } \\
\hline & 1 & 2 & 3 & 4 & 5 & 6 & 7 & 8 & 9 & 10 & & & & \\
\hline Thickness Tensile & 1 & 1.1 & 0.99 & 1 & 1 & 1 & 1.1 & 1.1 & 1 & 0.99 & 1 & 1.01 & 0.324 & 0.06 \\
\hline strength & 245 & 230 & 219 & 223 & 240 & 242 & 230 & 225 & 228 & 240 & 200 & 225.26 & 19.672 & 0 \\
\hline Elongation & 57 & 55 & 58 & 58 & 59 & 59 & 55 & 50 & 52 & 56 & 40 & 47.51 & 2.515 & 0.52 \\
\hline $\begin{array}{l}\text { Shrinkage } \\
\text { temperature }\end{array}$ & 102 & 102 & 101.8 & 102.5 & 102.2 & 102 & 102.1 & 102.5 & 102.5 & 102.4 & 102.5 & 102.24 & 0.2545 & 0.38 \\
\hline
\end{tabular}

From (Tables 7) the mechanical properties for both controlled and recycled leathers were in conformity with standards of SSMO $[15,16]$ and there were no significant differences between controlled and recycled leathers thus assessment of the finished leathers showed that skins un-haired in recycled liquors produced good quality leather (T2) with appearance break and feels similar to the control leathers (T1).

There was no significant difference in a real yield or tensile strength, elongation and shrinkage temperature tests: because there were no differences in break loads at grain and thermal stability.

\section{Conclusion}

It's concluded that:

I. Chemical and water can be saved through recycling.

II. The environment will be protected from the polluted chemicals.

III. The quality of the leather produced is satisfactory as compared with the standard specifications.

\section{Recommendation}

a) The recycling method from soaking through retannage is recommended. b) The method of recycling must be generalized to all tanneries as it saves chemicals, water, protects the environment and there is no need to construct a waste water treatment plant.

\section{References}

1. Thanikaivelan P, Rao JR, Nair BU, Ramasami T (2001) Approach towards zero discharge tanning: role of concentration on the development of eco - friendly liming-reliming processes. Journal of Cleaner Production 11(1): 79-90.

2. Thanikaivelan P, Rao JR,Nair BU, Ramasami $T$ (2005) Recent Trends in Leather Making: Processes, Problems, and Pathways, Critical Reviews in Environmental. Science and Technology Journal 35(1): 37-39.

3. Dargo H, Ayalew A (2014) Tannery Waste Water Treatment: A Review. Int J Emerg Tren Sci \& Tech 1(9): 1488-1494.

4. Buljan A, Kral I (2011) Introduction to Treatment Tannery Effluents. United Nations Industrial Development Organization Vienna pp: 1-69.

5. Kanagaraj J, Velappan KC, Chandra Babu NK Sadulla S (2006) Solid wastes generation in the leather industry and its utilization for cleaner A review. Environment Journal of Scientific \& Industrial Research 65: 541-548.

6. Puntener (1995) Ecological challenge of producing leather. Journal of the American leather chemists Association 90: 206-219.

7. European Commission (IPPC) (2013) Best available techniques for the tanning of hide and skins.

8. International Environment Commission (IUE) (1996) typical pollution values related to conventional tannery processes World leather 9(7): 13. 
9. ASTM International: D1239 (2005) Standard test method for $\mathrm{pH}$ of water. 100 Barr Harbor Drive, PA 19428-2959, USA.

10. ASTM International: D5907/13 (2014) Standard test method for total dissolved solids of water. 100 Barr Harbor Drive, West Conshohocken, PA 19428-2959, USA.

11. ASTM International: D6238 (2016) Standard test method for tota oxygen demand in water. 100 Barr Harbor Drive, West Conshohocken, PA 19428-2959, USA.

12. ASTM International: D1252/18 (2016) Standard Test Method for Chemical Oxygen Demand in water. 100 Barr Harbor Drive, West Conshohocken, PA 19428-2959, USA.
13. Society of Leather Trades Chemists (S.L.T.C.) 1996. Official methods of analysis. Ninth revised edition- Society of leather trades chemists. Nortampton, UK.

14. Barakat, N, M, (2013). Statistical Packages for the Social Sciences. College of Trade, Islamic University, Pp 154-158.

15. Sudanese Standard and Metrology Organization (S.S.M.O.5) (2003) Leather metrology: leather physical tests- Tensile Strength. Khartoum, Sudan.

16. Sudanese Standard and Metrology Organization (S.S.M.O.6) (2001) Leather metrology: physical tests for shoe upper leather- Khartoum, Sudan. 